\title{
SOSIALISASI PERATURAN BANTUAN HUKUM DALAM UPAYA PEMENUHAN PRINSIP EQUALITY BEFORE THE LAW WARGA BINAAN LEMBAGA PEMASYARAKATAN KELAS IIA KUNINGAN, INDONESIA
}

\author{
Haris Budiman \\ Fakultas Hukum, Universitas Kuningan, Kuningan, Indonesia \\ Email: harisbudiman9@yahoo.co.id
}

\begin{abstract}
The reality in the society of equality before the law and the protection of the law can't easily be realized. Differences in ability, both economically and intellectually, make it difficult for justice seekers to access justice. Discrimination often occurs against marginalized communities, ranging from rulemaking, implementation, to law enforcement. Therefore, we are motivated to do the devotion by providing socialization, counseling, consultation and assistance for residents of Kuningan Regency in this case the citizens of the IIA Kuningan class correctional institution who want to seek justice. this activity received a very good response, not only for the assisted citizens, but also for the officers and employees in charge. The material given in the form of film screenings about legal aid made by BPHN and the Ministry of Justice and Human Rights of Indonesia, as well as discussion material prepared by the Community Service Team. The expected outcome of this devotion is the opening of access to legal guarantees for the disadvantaged and marginalized, so that the basic principle of the law State of equality before the law is fulfilled.
\end{abstract}

Keywords: Legal Aid, Establishment, Equality

\section{Abstrak}

Kenyataan di masyarakat persamaan di hadapan hukum dan perlindungan hukum tidak dengan mudah dapat terwujud. Perbedaan kemampuan, baik secara ekonomis maupun secara intelektual, menyebabkan sulitnya para pencari keadilan dalam mengakses keadilan (acces to justice). Diskriminasi sering terjadi terhadap masyarakat marginal, mulai dari pembuatan aturan hukum, pelaksanaan, sampai dengan penegakan hukum. Oleh karena itu, kami tergerak untuk melakukan pengabdian dengan memberikan sosialisasi, penyuluhan, konsultasi dan pendampingan bagi warga masyarakat Kabupaten Kuningan dalam hal ini warga binaan lembaga pemasyarakatan kelas IIA Kuningan yang ingin mencari keadilan. kegiatan ini mendapat respon yang sangat baik, tidak saja bagi warga binaan, tetapi juga bagi aparat dan pegawai yang bertugas. Materi yang diberikan berupa pemutaran film tentang bantuan hukum yang dibuat oleh BPHN dan Kementerian Hukum dan HAM RI, juga materi diskusi yang disiapkan oleh Tim Pengabdian Masyarakat. Luaran yang diharapkan dari pengabdian ini adalah terbukanya akses terhadap jaminan hukum bagi masyarakat tidak mampu dan terpinggirkan, sehingga prinsip dasar Negara hukum yaitu equality before the law terpenuhi.

Kata kunci : Bantuan Hukum, Warga Binaan, Persamaan

\section{PENDAHULUAN}

Indonesia adalah negara hukum, dalam Negara hukum, negara mengakui dan melindungi hak asasi manusia bagi setiap individu termasuk hak atas bantuan hukum, antara lain meliputi, hak kesamaan di hadapan hukum (equality before the law), dan hak atas pengakuan, jaminan, perlindungan, dan kepastian hukum yang adil, serta hak atas perlakuan yang sama dihadapan atau dalam proses hukum. ${ }^{1}$ Namun dalam kenyataanya persamaan di hadapan hukum dan perlindungan hukum tidak dengan mudah dapat terwujud. Perbedaan kemampuan, baik secara

\footnotetext{
1 Muhammad Tahir Azhary, Negara Hukum, Prenada Media, Jakarta, 2003, hlm 89
} 
ekonomis maupun secara intelektual, menyebabkan sulitnya para pencari keadilan dalam mengakses keadilan (acces to justice). Diskriminasi sering terjadi terhadap masyarakat marginal, mulai dari pembuatan aturan hukum, pelaksanaan, sampai dengan penegakan hukum. Oleh karena itu, demi terwujudnya persamaan dan perlakuan di hadapan hukum, bantuan hukum mutlak diperlukan. Bantuan hukum bukan hanya prasyarat untuk memenuhi Hak Konstitusional warganegara, tetapi juga merupakan salah satu Hak Konstitusional warganegara yang harus dijamin pemenuhannya oleh negara, terutama kelompok masyarakat miskin.

Mengapa lingkungan masyarakat miskin menjadi perhatian pemerintah? Karena sampai saat ini jumlah orang miskin di Indonesia masih relatif banyak. Data BPS tahun 2015 menyebutkan masih berkisar 27,73 orang miskin. Negara perlu hadir memberikan perhatian lebih bagi mereka agar bangsa Indonesia bisa bangkit menjadi negara maju di antara Negara ASEAN yang lain. Hal ini perlu dilakukan seiring dengan penguatan arus demokratisasi dan hak Asasi Manusia, bahwa negara memberikan jaminan perlindungan hukum, khususnya bagi warga negara yang tidak mampu. Hal ini merupakan prinsip negara hukum sebagaimana ditegaskan dalam Pasal 1 ayat (3) UUD 1945. Oleh karena itu prinsip supremasi hukum dan persamaan kedudukan di muka hukum harus dijalankan dengan sebaik-baiknya.
Untuk mewujudkan hal ini diperlukan keseimbangan, sehingga seseorang yang tidak mampu menjalankan proses hukum tetap dapat memperoleh pembela yang profesional. Jika tidak, maka akan sulit bagi orang miskin yang berperkara mengapai keadilan. Dampaknya adalah bangsa Indonesia akan kesulitan mencapai target SDGs.

Dalam konteks inilah, bantuan hukum untuk orang miskin menjadi kewajiban negara (state obligation) dalam rangka memastikan prinsipprinsip negara hukum berjalan dengan baik. Kewajiban negara ini sesuai dengan International Covenant on Civil and Political Rights Pasal 14 yang mengatur tentang persamaan hak di pengadilan. Untuk mengimplementasikan tuntutan negara hukum inilah dihadirkan Undang-Undang Nomor 16 tahun 2011 tentang Bantuan Hukum, yang diharapkan dapat melindungi hak konstitusional setiap individu untuk mendapatkan bantuan hukum selain itu juga diharapkan dapat mengakomodir perlindungan terhadap masyarakat yang kurang mampu dalam menghadapi kasus-kasus hukum.

Bantuan hukum bukan diberikan oleh negara dan bukan belas kasihan dari negara, tetapi juga merupakan tanggung jawab negara dalam mewujudkan equality before the law, acces to justice, dan fair trial. Dengan demikian pengakuan dan jaminan terhadap asas Equality Before the Law ini tidak saja sebatas 
pengakuan politik negara saja. Akan tetapi lebih mengedepankan tindakan konkrit negara dalam memberikan jaminan kepada masyarakat mendapatkan akses terhadap keadilan guna terpenuhi hak-hak dasar manusia (HAM), bahkan tindakan afirmatif juga harus dilakukan untuk menjamin terselengaranya kewajiban negara ini. Dengan derasnya laju pertumbuhan pembangunan dan politik di Indonesia memunculkan permasalahanpermasalahan mendasar yang meminggirkan bahkan mengabaikan hak-hak dasar manusia yang berujung kepada kriminalisasi dan memposisikan rakyat untuk meminta hak atas keadilan di Pengadilan maupun di luar pengadilan guna mendapatkan keadilan.

Bantuan hukum adalah hak konstitusional setiap warga. Lahirnya UU Bantuan Hukum seharusnya menjadi wujud nyata tanggung jawab negara terhadap Hak Atas Bantuan Hukum sebagai akses keadilan bagi seluruh masyarakat Indonesia sebagaimana diamanahkan oleh UUD 1945, UU Nomor 39 tahun 1999 tentang Hak Asasi Manusia (HAM), Kitab Undang-undang Hukum Acara Pidana (KUHAP), Deklarasi Universal Hak Asasi Manusia, pasal 14(3)(d) Kovenan Internasional tentang HakHak Sipil dan Politik (International Covenant on Civil and Political Rights) yang telah disahkan melalui UndangUndang Nomor 12 tahun 2005, juga ada pemberian jaminan bagi setiap orang untuk mendapatkan bantuan hukum dan pelayanan dari Advokat ( a right to have a legal counsel) yang berkualitas bagi masyarakat miskin.

Sesuai praktek internasional, ada 5 pilar mengenai bantuan hukum yakni:

a. Accesible, bantuan hukum harus dapat diakses dengan mudah;

b. Affordability, bantuan hukum dibiayai oleh negara;

c. Sustainable, bantuan hukum harus terus ada dan tidak tergantung pada donor sehingga negara harus menganggarkannya dalam APBN;

d. Credibility, bantuan hukum harus dapat dipercaya dan memberikan keyakinan bahwa yang diberikan adalah dalam rangka peradilan yang tidak memihak (juga saat mereka menghadapi kasus melawan negara, tidak ada keraguan tentang itu); serta

e. Accountability, pemberi bantuan hukum harus dapat memberikan pertanggungjawaban keuangan.

Konsepsi bantuan hukum dalam UU Bantuan Hukum merupakan bantuan pembiayaan dari Negara bagi masyarakat miskin yang berhadapan dengan hukum. Sebelumnya, Negara tidak melakukan pemenuhan hak atas bantuan hukum bagi masyarakat. Peranan tersebut dimulai dan terus dilakukan secara mandiri dan swadaya oleh masyarakat. Dengan dikeluarkannya Undang-Undang Nomor 16 Tahun 2011 tentang Bantuan Hukum, maka setiap warga masyarakat yang terbelit masalah hukum sekiranya mendapatkan perlindungan terhadap penegakan hak-hak tersangka dan 
terdakwa. Negara, dalam hal ini adalah pemerintah, berkewajiban untuk memastikan bahwa setiap orang yang tidak mampu mendapatkan akses untuk mendapatkan bantuan hukum secara cuma-cuma kepada para pencari keadilan yang tidak mampu.

Sebagai akademisi yang merupakan bagian dari masyarakat, kami memiliki tri dharma perguruan tinggi. Tidak saja memberikan pengajaran dan penelitian, tetapi juga menyelenggarakan pengabdian pada masyarakat Memberikan bantuan hukum bagi masyarakat yang membutuhkan adalah bagian dari pelaksanaan pengabdian masyarakat yang bisa dilakukan oleh dosen atau tim dosen beserta mahasiswa Fakultas Hukum, apalagi di Fakultas Hukum Universitas Kuningan telah dibentuk Pusat Konsultasi dan bantuan Hukum (PKBH) yang bertujuan untuk memberikan penyuluhan, konsultasi dan pendampingan bagi warga masyarakat Kabupaten Kuningan yang ingin mencari keadilan. Penyelenggaran bantuan hukum yeng bertujuan untuk mencapai keadilan memerlukan partisipasi dari masyarakat secara luas untuk berperan dalam mendukung peyelenggaraan pemerintahan. $^{2}$

Adanya memorandum of understanding atau kesepakatan bersama, yang ditandatangani oleh

\footnotetext{
2 Suwari Akhmaddhian dan Anthon Fathanudien. Partisipasi Masyarakat dalam Mewujudkan Kuningan sebagai Kabupaten Konservasi (Studi di Kabupaten Kuningan). Jurnal $\begin{array}{lllll}\text { UNIFIKASI } & \text { Vol. } & 2 & \text { (1). }\end{array}$ DOI: https://doi.org/10.25134/unifikasi.v2i1.26
}

Bupati Kuningan mewakili Pemerintah Daerah Kabupaten Kuningan beserta Ketua Pengadilan Negeri Kuningan, aparat penegak hukum dan organisasi bantuan hukum, tentunya merupakan arah yang positif dalam upaya penegakan dan perlindungan hukum. Oleh karena itu sebagai bagian dari civitas akademika, kami tergerak untuk memberikan sosialisasi mengenai Undang Undang Bantuan Hukum kepada warga binaan pada Lembaga Pemasyarakatan Kelas IIA Kuningan.

\section{METODE PELAKSANAAN}

Metode yang digunakan dalam kegiatan ini yaitu melalui kegiatan ceramah dan diskusi ynag didasarkan pada permasalahan, bahwa pemerintah sangat kurang memberikan sosialisasi Undang Undang Nomor 11 tahun 2016 tentang Bantuan Hukum. Hal ini dapat dipahami karena Pemerintah memiliki keterbatasan sumber daya, oleh karena itu menjadi suatu kewajiban bagi kami untuk berperan aktif membantu pemerintah memberikan sosialisasi pada masyarakat, termasuk warga binaan yang sangat membutuhkan karena sedang tersangkut masalah hukum.

Oleh karena itu solusi untuk menyelesaikan berbagai permasalahan tersebut adalah: pertama, melakukan penyuluhan hukum secara berkala dan berkelanjutan satu bulan dua kali, dimana setiap pertemuan dihadiri oleh 15-20 peserta dari warga binaan, dikhususkan warga yang masih dalam 
proses penyidikan, warga titipan kepolisian atau kejaksaan dan belum mendapat putusan dari Pengadilan. Kedua, membuka akses untuk memberikan pendampingan baik melalui jalur litigasi dan non litigasi terhadap warga binaan yang membutuhkan, dengan terlebih dahulu dipenuhi semua persyaratan yang diperlukan sebagaimana tercantum dalam undang undang bantuan hukum. Ketiga, memberikan wawasan dan kesadaran untuk segera keluar dari keterpurukan yang sedang dihadapi, kembali memulai kehidupan yang produktif dan positif dengan mematuhi semua ketentuan dan peraturan yang berlaku

\section{HASIL DAN PEMBAHASAN}

Pelaksanaan kegiatan sosialisasi Undang Undang Bantuan Hukum pada warga binaan di Lembaga Pemasyarakatan Kelas IIA Kuningan diawali dengan kesepakatan bersama antara Fakultas Hukum Universitas Kuningan dengan Lembaga Pemasyarakatan Kelas II A Kuningan yang dituangkan dalam perjanjian kerja sama tentang Bimbingan dan Konsultasi Bantuan Hukum Bagi Warga Binaan Pemasyarakatan Lapas Kelas II A Kuningan, yang ditandatangani oleh Dekan Fakultas Hukum dan Kepala Lembaga Pemasyarakatan Kelas II A Kuningan pada tanggal 27 April 2016.

Kegiatan sosialisasi Undang Undang bantuan Hukum dan pendampingan dilakukan setiap minggu kedua dan minggu keempat setiap bulannya. Peserta yang hadir berjumlah 20 (duapuluh) sampai 30 (tigapuluh) orang per kegiatan. Akan tetapi untuk kegiatan pendampingan yang akan menggunakan jalur litigasi dengan jasa advokat dilakukan tersendiri setelah kegiatan penyuluhan dilaksanakan.

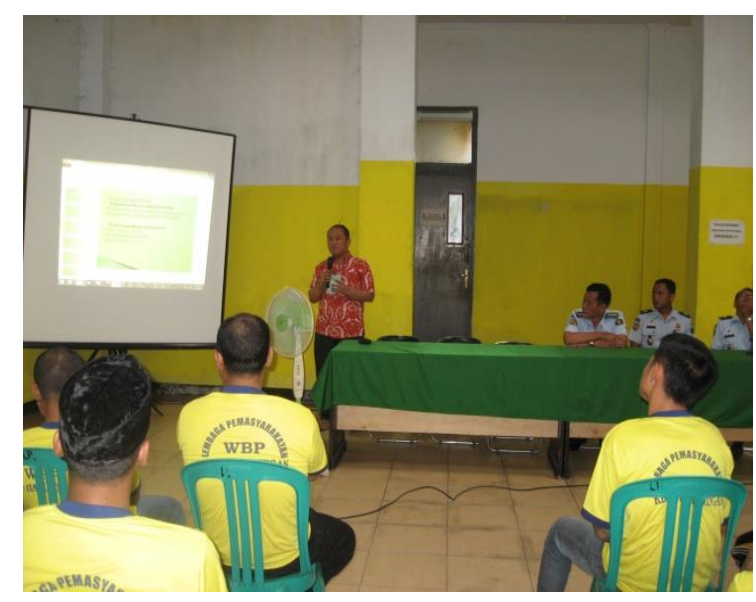

Hasil dari kegiatan pengabdian masyarakat dalam bentuk sosialisasi ini merupakan langkah solitif atas kurangnya akses terhadap pendampingan perkara yang sedang menimpa warga binaan, serta kurangnya sosialisasi tentang bantuan hukum bagi warga binaan. Oleh karena itu kegiatan ini mendapat respon yang sangat baik, tidak saja bagi warga binaan, tetapi juga bagi aparat dan pegawai yang bertugas di Lapas kelas II A Kuningan. Materi yang diberikan dalam kegiatan sosialisasi ini berupa pemutaran film tentang bantuan hukum yang dibuat oleh BPHN dan Kementerian Hukum dan HAM RI, juga materi diskusi yang disiapkan oleh Tim Pengabdian Masyarakat. 
Bantuan hukum bagi masyarakat tidak mampu diberikan dalam bentuk litigasi dan non litigasi, bantuan hukum ini bertujuan untuk memberikan pelayanan dalam bidang hukum. ${ }^{3}$

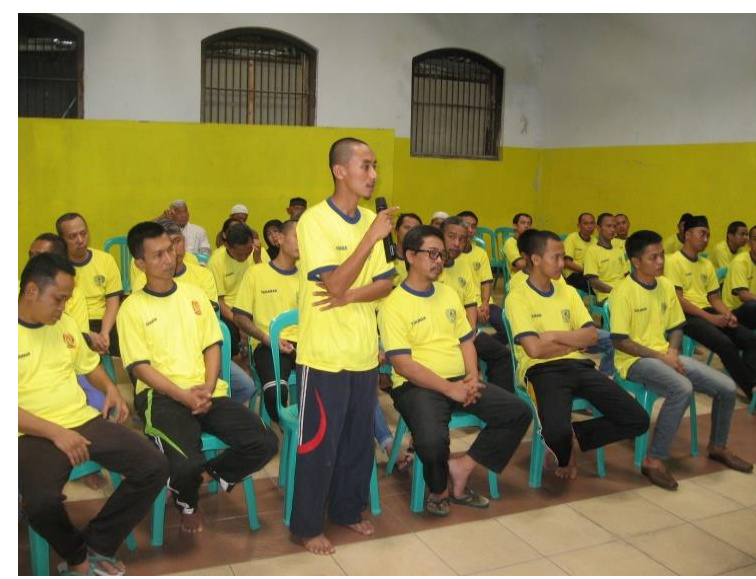

Disamping menyampaikan materi tentang Undang Undang Bantuan Hukum, tim pengabdian juga memberikan wawasan tentang ciri-ciri Negara hokum, yang dikutif dari $A C$ Dicey, yang mengemukakan bahwa suatu Negara hukum harus memiliki ciri-ciri :

a. Supremasi hukum dalam arti tidak boleh ada kesewenang-wenangan, sehingga seseorang hanya boleh dihukum jika melanggar hokum

b. Kedudukan yang sama di depan hukum

c. Terjaminnnya hak-hak manusia oleh undang undang dan keputusan-keputusan pengadilan. ${ }^{4}$

\footnotetext{
${ }^{3}$ Diding Rahmat. Implementasi Kebijakan Program Bantuan Hukum Bagi Masyarakat Tidak Mampu di Kabupaten Kuningan. ISSN 2354-5976 Vol. 04 Nomor 01 Januari 2014, hlm. 35-42. Doi : https://doi.org/10.25134/unifikasi.v4i1.478 ${ }_{4}$ Mahfud MD, Politik Hukum di Indonesia, Rajawali Pers, Jakarta, 2008, hlm 8
}

Untuk kegiatan pendampingan yang menggunakan jalur litigasi, warga binaan yang dikatagorikan orang atau kelompok masyarakat miskin cukup menyerahkan Surat Keterangan Miskin yang dikeluarkan oleh Desa/Kelurahan, atau yang sejenisnya misalnya Bantuan Langsung Tunai, Kartu Indonesia Sehat, Kartu Indonesia Pintar dan sebagianya. Jika masih kesulitan dalam mendapatkan Surat Keterangan Miskin, maka Organisasi Bantuan Hukum dapat mengeluarkan Surat Keterangan Miskin yang ditandatangani oleh Direktur OBH dan diketahui oleh Kepala Rumah Tahanan atau Polisi atau Jaksa (aparat penegak hukum).

Sedangkan jenis layanan bantuan hukum yang bisa dikases oleh warga binaan meliputi:

1. Bantuan Hukum Litigasi yakni Bantuan Hukum pada proses peradilan, baik di tingkat Kepolisian, Kejaksaan maupun Persidangan yang meliputi semua kasus baik Pidana, Perdata dan Tata Usaha Negara.

2. Bantuan Hukum Non Litigasi, berupa 9 Jenis kegiatan, yaitu penyuluhan hokum, konsultasi hokum, investigasi perkara, penelitian hukum, mediasi, negosiasi, pemberdayaan masyarakat, pendampingan di luar pengadilan, dan drafting dokumen hukum.

\section{SIMPULAN dan SARAN}

Berdasarkan uraian di atas 
Simpulan

Berdasarkan pengamatan selama melakukan pengabdian masyarakat pada warga binaan di Lembaga Pemasyarakatan Kelas II A Kuningan, tim memperhatikan antusiasme peserta dalam kegiatan sosialisasi ini. Hal ini terlihat dari banyaknya pertanyaan yang diajukan dan keinginan untuk mendapatkan pendampingan baik menggunakan jalur litigasi maupun non litigasi. Warga binaan yang selama ini merasa sebagi kelompok yang terpinggirkan mulai menyadari akan pentingnya hak-hak mereka dalam mendapatkan akses bantuan hukum.

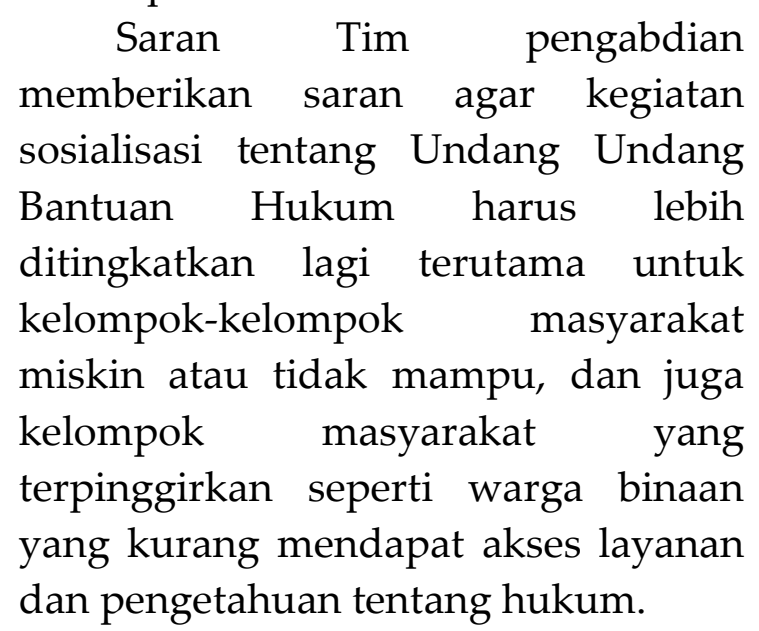

\section{DAFTAR PUSTAKA}

Diding Rahmat. Implementasi Kebijakan Program Bantuan Hukum Bagi Masyarakat Tidak Mampu di Kabupaten Kuningan. ISSN 23545976 Vol. 04 Nomor 01 Januari 2014, hlm. 35-42. Doi : https://doi.org/10.25134/unifikas i.v4i1.478

Mahfud MD, 2008, Politik Hukum di Indonesia, Rajawali Pers, Jakarta

Muhammad Tahir Azhary, 2003, Negara Hukum, Prenada Media, Jakarta
Suwari Akhmaddhian dan Anthon Fathanudien. Partisipasi Masyarakat dalam Mewujudkan Kuningan sebagai Kabupaten Konservasi (Studi di Kabupaten Kuningan). Jurnal UNIFIKASI Vol. $2 \quad$ (1). 2015. DOI: https://doi.org/10.25134/unif ikasi.v2i1.26

Undang Undang Dasar Negara Republik Indonesia Tahun 1945 Undang Undang Nomor 16 Tahun 2011 tentang Bantuan Hukum 